\title{
Pemberdayaan Masyarakat Melalui Pengembangan Usaha Budidaya Lele Dalam Menghadapi Pandemi Covid-19
}

\author{
Mayang Ramadhanti ${ }^{1^{*}}$, Agustin Rita Lestari ${ }^{2}$, Dina Fatma Dewi ${ }^{3}$, Tutik Indrawati ${ }^{4}$ \\ , Katharina Devi Hilda ${ }^{5}$, Anis Kusniati ${ }^{6}$, Agus Setyawan ${ }^{7}$, Moh. Ahsan $^{8}$ \\ 1-8 Universitas Kanjuruhan Malang \\ ${ }^{*}$ Corresponding author \\ E-mail: ramadhanti.mayang@gmail.com
}

Article History:

Received: 14-09-2020

Revised: 28-10-2020

Accepted: 31-10-2020

\begin{abstract}
Munculnya wabah penyakit Corona Virus Diseases-19 (Covid-19) sangat mempengaruhi kehidupan manusia. Pemberdayaan masyarakat terdampak covid-19 di Desa Sitirejo Kecamatan Wagir Kabupaten Malang dengan cara mengoptimalkan potensi yang dimiliki desa. Tujuan dilakukannya pengabdian masyarakat ini yaitu untuk membantu masyarakat dalam menciptakan pendapatan sesuai dengan kemampuan dan kompetensi dari masyarakat tersebut agar mereka dapat mandiri, berkembang serta tidak selalu bergantung dari bantuan pemerintah dengan cara membantu peningkatan kelangsungan usaha budidaya lele milik warga. Masyarakat perlu mengetahui betapa pentingnya untuk tetap berwirausaha dalam masa pandemi ini. Tahapan kegiatan dirancang selama 1 minggu yang didahului dengan kegiatan koordinasi dan komunikasi dengan pihak desa Sitirejo. Persiapan dimaksudkan adalah penetapan sasaran kegiatan, dan lokasi kegiatan. Hasil kegiatan ini sangat sesuai dengan yang diharapkan yaitu pada kegiatan yang dilaksanakan dapat membantu masyarakat yang secara aktif melalui bantuan 3.000 bibit lele guna membantu peningkatan jiwa wirausaha masyarakat desa Sitirejo.

Covid-19, Pemberdayaan Masyarakat, Pengabdian
\end{abstract}

Keywords:

\section{Pendahuluan}

Secara geografis, Desa Sitirejo terletak pada posisi $7^{\circ} 96^{\prime}-7^{\circ} 02^{\prime}$ Lintang Selatan dan $111^{\circ} 31^{\prime}-112^{\circ} 61^{\prime}$ Bujur Timur. Topografi ketinggian desa ini adalah berupa daratan sedang yaitu sekitar $413 \mathrm{~m}$ di atas permukaan air laut. Luas Wilayah Desa Sitirejo adalah $257 \mathrm{Ha}$. Luas lahan yang ada terbagi ke dalam beberapa peruntukan, yang dapat dikelompokkan seperti untuk fasilitas umum, pemukiman, pertanian, perkebunan, kegiatan ekonomi dan lain-lain. Berdasarkan data Administrasi Pemerintahan Desa tahun 2018, jumlah penduduk Desa Sitirejo adalah 10.364 jiwa, dengan rincian 5.235 laki-laki dan 5.129 perempuan. Jumlah penduduk demikian ini tergabung dalam 2.927 KK (Sitirejo, 2020).

Maret 2020, Organisasi Kesehatan Dunia (WHO) menyatakan wabah Covid-19 sebagai pandemi hanya sekitar 3 bulan setelah kemunculannya pada Desember 2019 di Wuhan, Cina. Penyebaran virus ini sekarang menjadi masalah kesehatan dunia. Pada 31 Maret 2020, Covid-19 memengaruhi 200 negara dan wilayah (Jalali et al., 2020). Indonesia hingga 21 April 2020 telah mencatat sebanyak 7.135 pasien positif, dengan 842 telah sembuh dan 616 meninggal dunia 
(Wisnuwardani, 2020). Lima provinsi dengan sebaran terbanyak pasien positif adalah DKI Jakarta, Jawa Barat, Jawa Timur, Jawa Tengah, dan Sulawesi Selatan. Sementara di Provinsi Kalimantan Barat sampai dengan artikel ini ditulis tanggal 21 April 2020, jumlah pasien positif Covid-19 berjumlah 27 orang, dengan rincian 7 orang sembuh dan 3 orang meninggal dunia (Guritno, 2021).

Berdasarkan hasil wawancara dengan kepala desa dan kepala dusun, terkait dengan adanya pademi Covid-19 yang berdampak besar terhadap warga, kabar pandemi virus ini membuat cemas dan berbagai upaya mengangkat moral serta semangat publik menghadapi dengan tegar sebaran Covid-19 melalui media sosial sampai juga ke masyarakat desa dan membuat mereka khawatir. Dampak pandemi ini sangat terasa terhadap kondisi perekonomian mereka (Saputra \& Putra, 2020; Sarip et al., 2020). Penghasilan dari kepala keluarga yang selama ini menjadi tumpuan utama mengalami penurunan signifikan. Sedangkan di sisi lain biaya kehidupan seperti untuk pangan, pendidikan dan biaya lainnya masih tetap sama. Desa Sitirejo merupakan desa yang mayoritas warganya bermata pencaharian sebagai petani dan peternak. Oleh karena itu, masyarakat di desa Sitirejo ditetapkan sebagai sasaran dari kegiatan pengabdian ini. Bidang ekonomi ditentukan sebagai sarana untuk mewujudkan pengabdian (Ginting et al., 2020; Yamali \& Putri, 2020). Terdapat 3 Mitra pembudidaya lele di desa Sitirejo ini, dimana 3 mitra tersebut yaitu Dusun Temu, Buwek dan Sarimadu yang dikelola oleh Pak Budi, Pak Agus dan Pak Bayu mereka adalah warga desa Sitirejo. Selain itu bapak Bayu selaku pengelola budidaya lele di dusun Sarimadu mengatakan warga mengeluh dengan adanya pandemi Covid-19 ini, usaha mereka mengalami penurunan dan terancam tutup karena kurangnya pendapatan karena menurunnya penjualan, dengan adanya bantuan 3.000 bibit lele untuk 3 dusun di desa Sitirejo ini sangat membantu kelancaran mengembangkan usaha ini. Selain itu hasil dari pengembangan bibit lele dapat dikonsumsi oleh warga sekitar karena ikan merupakan sumber pangan berbasis protein hewani dengan kondisi saat ini diburu masyarakat dikarenakan dapat meningkatkan daya tahan tubuh guna mencegah paparan Covid-19.

Dengan demikian, PkM ini dilaksanakan dengan tujuan untuk membantu masyarakat agar tetap produktif di masa pandemi Covid-19 dengan mengembangkan usaha budidaya lele. Aspek ekonomi menjadi prioritas dalam kegiatan PkM dengan pertimbangan, bahwa masyarakat desa rentan terkena dampak dari kebijakan penanggulangan penyebaran Covid-19 yang dilakukan oleh pemerintah.

\section{Metode}

Pengabdian kepada masyarakat ini dilakukan di tiga dusun di desa Sitirejo, kecamatan Wagir, kabupaten Malang. Ketiga dusun tersebut yaitu dusun Temu, dusun Buwek, dan dusun Sariasri. Pelaksanaan kegiatan PkM ini dimulai sejak 13 juli sampai 25 agustus 2020. Dimulai dengan tahap persiapan, survei bibit lele, pembelian bibit lele, pembagian bibit lele, evaluasi dan pelaporan hasil kegiatan. 
Persiapan kegiatan pengabdian meliputi musyawarah dengan kepala desa Sitirejo dan koordinasi dengan kepala dusun yang ada di desa Sitirejo untuk pelaksanaan kegiatan pengabdian. Penyiapan tempat budidaya lele kita koordinasi langsung dengan pembudidaya ikan. Untuk memecahkan permasalahan yang dihadapi dalam kegiatan pengabdian ini maka dirancang kegiatan yang terstruktur meliputi perizinan dengan perangkat desa kemudian survey tempat budidaya ikan.

\section{Hasil}

Permasalahan yang dihadapi warga desa Sitirejo yaitu bermula ketika pandemi covid-19 yang menyebabkan perekonomian warga menjadi menurun, maka dari keadaan tersebut kami membantu pengembangan budidaya lele dengan memberikan 3.000 bibit lele. Adapun rincian kegiatan yaitu (1) Persiapan dan survei bibit lele, persiapan diawali dengan melakukan diskusi dengan kepala desa dan kepala dusun di desa Sitirejo. Kesimpulan diskusi yaitu pemberian bibit lele kepada pembudidaya ikan yang ada di desa Sitirejo, selanjutnya kami melakukan survei ke tempat budidaya warga yang terletak di dusun Temu, Mbuwek dan Sari Asri; (2) Pembelian bibit lele, pembelian bibit lele dilakukan pada tanggal 2 agustus 2020 . Pembelian bibit ini dilakukan setelah kami berdiskusi dengan para pembudidaya; (3) Pembagian bibit lele, pembagian 3.000 bibit lele dilakukan pada tanggal 2 agustus 2020 di tiga dusun di desa Sitirejo yaitu dusun Temu, dusun Buwek, dan dusun Sari Asri. Masing-masing dusun mendapatkan 1.000 bibit lele.

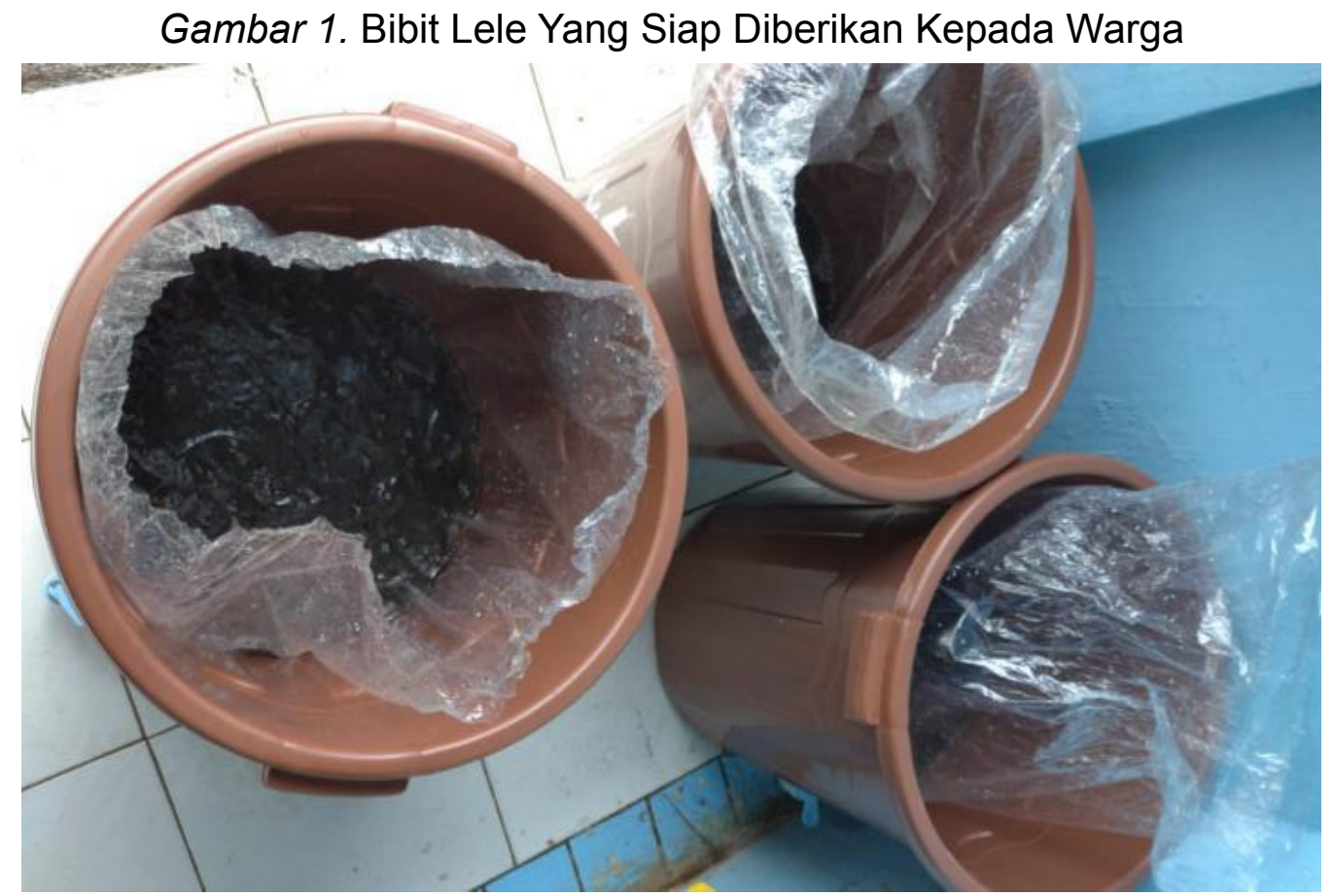




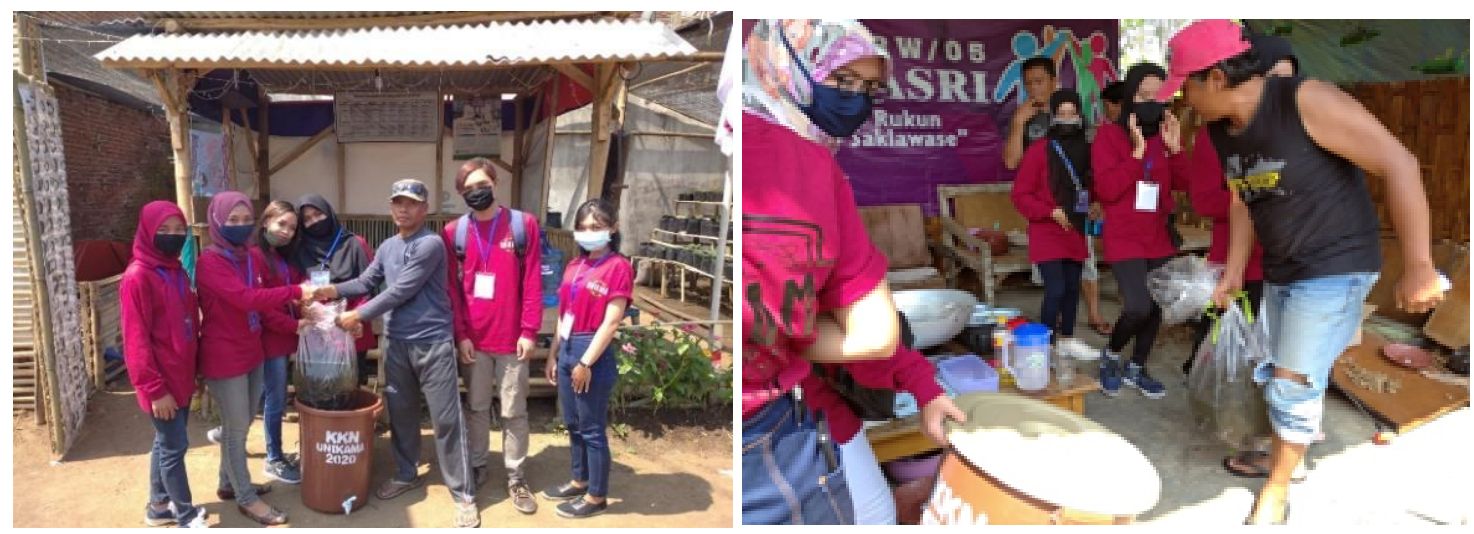

Gambar 2. Pelaksanaan Pembagian 3.000 Bibit Lele Kepada Warga

\section{Diskusi}

Secara administratif, Desa Sitirejo terletak di wilayah Kecamatan Wagir Kabupaten Malang dengan posisi dibatasi oleh wilayah desa-desa tetangga. Di sebelah Utara berbatasan dengan Kelurahan Kebonsari Kecamatan Sukun Kota Malang. Di sebelah barat berbatasan dengan Desa Parangargo Kecamatan Wagir. Di sisi selatan berbatasan dengan Desa Mendalanwangi Kecamatan Wagir, sedangkan di sisi timur berbatasan dengan Desa Kebonagung Kecamatan Pakisaji (Sitirejo, 2020).

Luas wilayah Desa Sitirejo adalah $257 \mathrm{Ha}$. Luas lahan yang ada terbagi ke dalam beberapa peruntukan, yang dapat dikelompokkan seperti untuk fasilitas umum, pemukiman, pertanian, perkebunan, kegiatan ekonomi dan lain-lain (Sitirejo, 2020). Luas lahan yang diperuntukkan untuk pemukiman adalah 109,4817 Ha. Luas lahan yang diperuntukkan untuk Pertanian adalah 91,5334 Ha. Luas lahan untuk ladang tegalan dan perkebunan adalah 49,6851 Ha. Sedangkan luas lahan untuk fasilitas umum adalah sebagai berikut: untuk perkantoran 0,681 $\mathrm{Ha}$, sekolah 3,186 $\mathrm{Ha}$, olahraga 5,775 $\mathrm{Ha}$, dan tempat pemakaman umum 2,6356 Ha (Sitirejo, 2020).

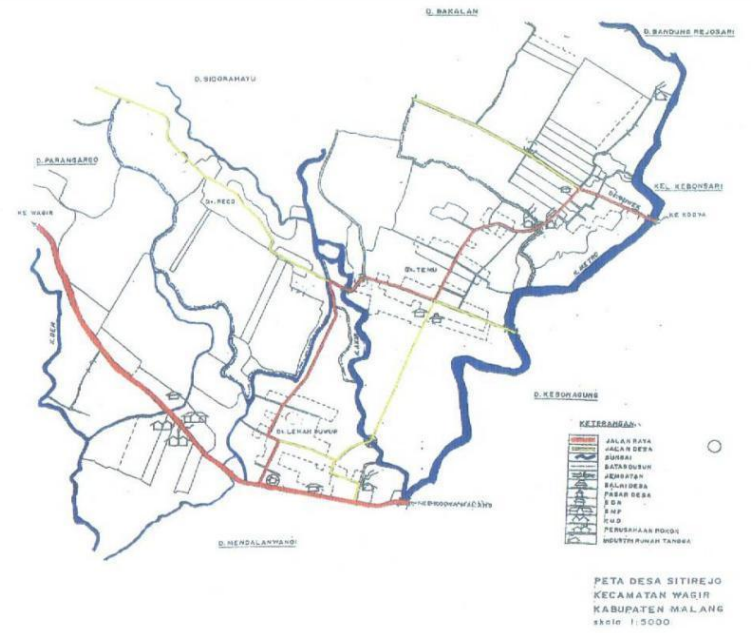

Gambar 3. Peta Desa Sitirejo 
Potensi dan hambatan didapatkan dari pengolahan hasil musrenbangdes, wawancara, dan observasi per-dusun. Berbagai data yang masuk kemudian ditampilkan dan dipilah untuk ditarik sebagai potensi dan hambatan pembangunan Desa Sitirejo. Dari sini tergambar dan dapat teridentifikasi bahwa Desa Sitirejo memiliki potensi yang sangat besar, baik sumber daya manusia maupun sumber daya alam. Sampai saat ini, potensi sumber daya yang ada belum benar-benar optimal diberdayakan. Hal ini terjadi dikarenakan belum teratasinya berbagai hambatan dan tantangan yang ada. Hambatan tersebut diantaranya adalah (1) Sumber Daya Alam, seperti lahan pertanian (sawah) yang masih dapat ditingkatkan produktivitasnya karena saat ini belum dikerjakan secara optimal; lahan perkebunan dan pekarangan yang subur, belum dikelola secara maksimal; wilayah Desa Sitirejo sangat baik untuk mengembangkan peternakan seperti sapi, kambing, bebek, dan ternak lain, mengingat banyaknya pakan untuk jenis ternak tersebut, sedangkan bidang usaha ini baru menjadi usaha sampingan; banyaknya sisa kotoran ternak sapi dan kambing, memungkinkan untuk dikembangkan usaha pembuatan pupuk organik; adanya usaha mebel dan perbengkelan. Selanjutnya adalah (2) Sumber Daya Manusia, seperti siklus dan ritme kehidupan warga masyarakat yang dari masa ke masa relatif teratur dan terjaga adatnya, hubungan yang baik dan kondusif antara kepala desa, pamong desa, dan masyarakat merupakan publik sphere yang ideal untuk terjadinya pembangunan desa, besarnya penduduk usia produktif disertai etos kerja masyarakat yang tinggi, cukup tingginya partisipasi masyarakat dalam perencanaan, pelaksanaan, pengawasan, dan monev pembangunan desa, masih hidupnya tradisi gotong royong dan kerja bakti masyarakat, Inilah salah satu bentuk partisipasi warga, masih adanya swadaya masyarakat (iuran untuk pembangunan), kemampuan bertani yang diwariskan secara turun-temurun, adanya kader kesehatan yang cukup, dari Bidan sampai para kader di posyandu yang ada di setiap dusun, adanya penduduk yang mampu membuat kerajinan permebelan kayu, adanya kelembagaan, organisasi, dan kelompok-kelompok, pertanian, berkoordinasi dalam setiap kegiatan proses pembangunan.

Pandemi COVID-19 memiliki dampak besar terutama pada sistem ekonomi, sosial dan politik (Zowalaty et al., 2020). Pembatasan sosial, karantina, penutupan sebagian besar lapangan pekerjaan berakibat sangat besar terhadap masyarakat. Sebagai bencana global, pandemi Covid-19 ini telah menginspirasi perubahan perilaku sosial termasuk solidaritas sosial. Situasi dan kondisi disaat pandemi ini telah mendorong berbagai aksi sosial, diantaranya pengabdian kepada masyarakat yang ditujukan secara khusus untuk membantu masyarakat penerima dampak. Aksi solidaritas ini dilakukan secara bersama-sama.

Dampak pandemi juga sangat terasa di desa Sitirejo, dari pertemuan dengan kepala desa dan kepala dusun didapatkan informasi bahwa ada beberapa warga yang kehilangan pekerjaan dan ada usaha budidaya ikan yang terancam tutup dikarenakan kurangnya modal. Usaha budidaya ini terletak di 3 dusun yaitu Temu, Buwek dan Sari Asri. Usaha ini dikelola oleh karang taruna dan ketua RT. Proses 
pengabdian ini dilakukan dengan memberikan bantuan berupa 3.000 ekor bibit lele untuk membantu usaha budidaya warga akan tetap bertahan. Setelah mendapatkan bantuan bibit, diharapkan agar usaha budidaya yang dilakukan oleh warga dapat berkembang dan bertahan di masa pandemi ini. Selain membantu warga dengan memberikan bibit, sebagai bentuk pengabdian, kami mengajak warga untuk menanam sayuran dengan memanfaatkan lahan yang ada di sekitar rumah. Mendukung rencana kami untuk mengajak warga memanfaatkan lahan, kami membantu dengan memberikan 390 polybag kangkung.

Selain itu kami juga mengajak warga untuk memahami protokol kesehatan saat ini yaitu dengan memasang tempat cuci tangan dan pamflet yang berisi ajakan untuk mencuci tangan dengan benar dan cara memakai masker yang benar. Hal ini kami lakukan setelah melakukan observasi dan kami menemui banyak warga yang belum mengetahui atau melalaikan protokol kesehatan seperti tidak memakai masker. Tempat cuci tangan diletakkan di area yang sering dikunjungi oleh warga seperti balai RW dan perempatan jalan di depan gang. Untuk pamflet dipasang di papan pengumuman di masing-masing desa dan di pos kamling. Tempat cuci dan pamflet diberikan ke 5 dusun yaitu Buwek, Temu, Reco, Lemahduwur dan Sari Asri.

\section{Kesimpulan}

Demikian laporan pengabdian masyarakat ini kami susun. Semoga laporan ini dapat dijadikan acuan dan bahan pertimbangan evaluasi untuk LPPM Universitas Kanjuruhan Malang mengenai kegiatan ini. Selain itu hal ini diharapkan dapat bermanfaat untuk masyarakat desa. Semoga pengabdian kami bisa berdampak baik di tengah masyarakat serta dapat berguna untuk menjaga ketahanan pangan di masa pandemi Covid-19 ini. Semoga masyarakat tetap produktif di masa pandemi Covid-19 dengan mengembangkan usaha budidaya lele. Bagi pelaksana kegiatan selanjutnya, semoga dengan adanya usaha pembudidayaan bibit lele ini dapat terus meningkatkan wirausaha masyarakat desa dan menjadi acuan bagi pelaksana selanjutnya untuk dapat menambah dan meningkatkan kegiatan tersebut dengan melakukan evaluasi dalam setiap kegiatan. Selain mengevaluasi kekurangan dari kelompok sebelumnya dengan melihat data-data yang ditemukan maka kami harapkan agar terus mendampingi pengembangan budidaya ikan lele yang sudah kami mulai. Hal ini menjadi penting agar kegiatan pengabdian masyarakat tidak sebatas lalu dan program yang sudah ada bisa berkelanjutan.

\section{Pengakuan/Acknowledgements}

Tim penulis mengucapkan terima kasih kepada Lembaga Pengabdian Pada Masyarakat (LPPM) Universitas Kanjuruhan Malang yang telah memberikan kesempatan untuk melaksanakan kegiatan di Desa Sitirejo sehingga terlaksana dengan baik. Terima kasih juga kami sampaikan kepada Kepala Desa, perangkat 
Desa Sitirejo Kecamatan Wagir, Kabupaten Malang, serta Pak Budi, Pak Agus dan Pak Bayu sebagai mitra pelaksanaan PKM yang sudah bersedia ditempatkan pelaksanaan PKM serta dukungannya.

\section{Daftar Referensi}

Ginting, R., Huda, M., Drifanda, V., \& Affandi, A. R. (2020). Pemberdayaan Masyarakat Desa Jungsemi di Masa Pandemi Covid 19 Melalui Pelatihan Pembuatan Hand Sanitizer dan Pelindung Wajah | Ginting | IJECS: Indonesian Journal of Empowerment and Community Services. IJECS: Indonesian Journal of Empowerment and Community Services, 1(1), 20-27. https://doi.org/10.32585/ijecs.v1i1.780

Guritno, T. (2021, March 9). 6.389 Kasus Baru Covid-19 Tersebar di 33 Provinsi, Jawa Barat Terbanyak dengan 1.787 Kasus Halaman all. KOMPAS.com. https://nasional.kompas.com/read/2021/03/09/18251891/6389-kasus-baru-co vid-19-tersebar-di-33-provinsi-jawa-barat-terbanyak-dengan

Jalali, M., Shahabi, S., Lankarani, K. B., Kamali, M., \& Mojgani, P. (2020). COVID-19 and disabled people: Perspectives from Iran. Disability \& Society, 35(5), 844-847. https://doi.org/10.1080/09687599.2020.1754165

Saputra, C., \& Putra, I. D. (2020). Pemberdayaan Penanggulangan Covid-19 Bagi Petugas Kesehatan. JCES (Journal of Character Education Society), 3(2), 320-328. https://doi.org/10.31764/jces.v3i1.2344

Sarip, S., Syarifudin, A., \& Muaz, A. (2020). Dampak Covid-19 Terhadap Perekonomian Masyarakat dan Pembangunan Desa. Al-Mustashfa: Jurnal Penelitian Hukum Ekonomi Syariah, 5(1), 10-20. https://doi.org/10.24235/jm.v5i1.6732

Sitirejo, D. (2020). Website Desa Sitirejo. http://sitirejo.desa.id/

Wisnuwardani, D. P. (2020, April 21). Update Corona 21 April 2020: 7.135 Positif COVID-19, 842 Sembuh, 616 Meninggal. liputan6.com. https://www.liputan6.com/health/read/4233568/update-corona-21-april-2020-7 135-positif-covid-19-842-sembuh-616-meninggal

Yamali, F. R., \& Putri, R. N. (2020). Dampak Covid-19 Terhadap Ekonomi Indonesia. Ekonomis: Journal of Economics and Business, 4(2), 384-388. https://doi.org/10.33087/ekonomis.v4i2.179

Zowalaty, M. E. E., Young, S. G., \& Järhult, J. D. (2020). Environmental impact of the COVID-19 pandemic - a lesson for the future. Infection Ecology \& Epidemiology, 10(1),

1768023. https://doi.org/10.1080/20008686.2020.1768023 